UDC $613,614,616.9$

DOI: 10.21668/health.risk/2021.2.05.eng

Research article

\title{
WATER PREAMMONIZATION AT CENTRAL WATER TREATMENT FACILITIES IN A LARGE CITY AS A WAY TO MINIMIZE HEALTH RISKS
}

\author{
S.A. Sosnina ${ }^{1}$, A.V. Mironovskaya ${ }^{1,2}$, T.N. Unguryanu ${ }^{1,2,3}$, R.V. Buzinov ${ }^{1,2}$ \\ ${ }^{1}$ Arkhangelsk Region Department of the Federal Service on Customers' Rights Protection and Human Well-Being \\ Surveillance, 24 Gaidara Str., Arkhangelsk, 163000, Russian Federation \\ ${ }^{2}$ Northern State Medical University, 51 Troitskii Ave., Arkhangelsk, 163000, Russian Federation \\ ${ }^{3}$ I.M. Sechenov First Moscow State Medical University, 2 Bldg., 2 Bol'shaya Pirogovskaya Str., Moscow, 119435, \\ Russian Federation
}

At present chlorine compounds are widely used to disinfect water during water treatment procedures; it stimulates occurrence of toxic chlorinated organic compounds. Water preammonization with ammonia sulfate was implemented at central water treatment facilities in Arkhangelsk.

Our research goal was to assess efficiency of water preammonization at central water treatment facilities in Arkhangelsk.

Our research involved analyzing drinking water quality at central water treatment facilities prior to preammonization was implemented (from January 2016 to July 2017) and after it was implemented (from June 2018 to December 2019). We examined 14,674 water samples prior to water preammonization implementation and 15,165 water samples after it. Water quality was analyzed as per 19 parameters. Non-carcinogenic effects caused by exposure to chemicals in drinking water, prior to and after preammonization, were estimated basing on calculating hazard quotients and indexes. To describe examined parameters, median and 90-th percentile was used. Wilcoxon signed-rank test was applied to reveal differences between water parameters prior to and after preammonization was implemented.

Water preammonization implemented at central water treatment facilities allowed improving drinking water quality at the second lifting and in distribution networks. After preammonization were implemented, aluminum concentration want down by 2.7 times at the second lifting; nitrates concentration, by 1.2 times; chloroform concentration, by 3.5 times $(p<0.001)$. Overall microbe number went down by 1.6 times $(p<0.001)$. After preammonization was implemented, water turbidity in distribution networks went down by 1.3 times, aluminum and chloroform concentrations fell by 1.7 and 7.3 times accordingly $(p<0.001)$. Contribution made by chloroform into hazard indexes decreased by $10-47 \%$ after preammonization was implemented against water treatment performed according to conventional procedures (chlorination).

Water preammonization allowed achieving more qualitative and efficient operating of water supply systems and operational costs reduction; it also resulted in a decrease in concentrations of adverse side products occurring due to disinfection and in achieving higher drinking water quality.

Key words: water preammonization, ammonia sulfate, water treatment, disinfection products, chlorinated organic compounds, chloroform, drinking water quality, central water treatment facilities, Arkhangelsk.

Drinking water quality is among the most essential factors affecting population health. High technogenic burden on the environment contributes significantly to the contamination of water bodies as indicated by chemical, biological and organoleptic properties of water [1-3]. Clean and safe drinking water supply and optimization of water usage are still ongoing tasks, despite improved water disinfection and purification technologies [3].

Sufficient drinking water disinfection and appropriate sanitary conditions at water treatment facilities are accomplished due to water chlorination, which is one of the most impor-

(C) Sosnina S.A., Mironovskaya A.V., Unguryanu T.N., Buzinov R.V., 2021

Svetlana A. Sosnina - Leading expert at the Sanitary Supervision Department (e-mail: stchupakova@yandex.ru; tel.: +7 (8182) 65-27-93; ORCID: https://orcid.org/0000-0003-0241-4111).

Anastasiya V. Mironovskaya - Candidate of Medical Sciences; Deputy Head; Associate Professor at the Department for Hygiene and Medical Ecology (e-mail: miro_av@mail.ru; tel.: +7 (8182) 20-57-23; ORCID: http://orcid.org/0000-0001-9849-2848).

Tatiana N. Unguryanu - Doctor of Medical Sciences, Chief Expert; Professor at the Department for Hygiene and Medical Ecology; Professor at the Common Hygiene Department (e-mail: unguryanu_tn@mail.ru; tel.: +7 (8182) 21-04-61; ORCID: http://orcid.org/0000-0001-8936-7324).

Roman V. Buzinov - Doctor of Medical Sciences, Head; Professor at the Department for Hygiene and Medical Ecology (e-mail: arkh@29.rospotrebnadzor.ru; tel.: +7 (8182) 20-05-69; ORCID: https://orcid.org/0000-0002-8624-6452). 
tant stages in water conditioning and purification [4]. However, drinking water chlorination involves occurrence of disinfection byproducts (DBPs). Water treatment using chlorine-containing reagents results in occurrence of more than 300 toxic chlorinated organic compounds, primarily those that belong to trihalomethanes (THMs) (chloroform, dichlorobromomethane, chlorodibromomethane, bromoform, and others) [4, 5]. And chloroform is one of the most common disinfection byproducts with its concentration significantly exceeding contents of other chlorinated volatile organic compounds ${ }^{1}$ [6-8]. In addition, even a small amount of chlorine in drinking water gives it a very distinctive odor that consumers can easily sense.

Chronic exposure to THMs poses a significant risk to population health as they are considered systemic toxicants, are mutagenic and carcinogenic [9-11], genotoxic, cause metabolic disorders [12], and contribute to an increase in overall and infant morbidity rates [13]. Even a small amount of THMs, in particular chloroform, in drinking water leads to elevated risks of carcinogenic and general toxic effects [14].

Contents of chlorinated organic compounds in drinking water can be decreased via preliminary ammonization, that is, water that is being chlorinated contains ammonium nitrogen [15]. The essence of the method lies in introducing ammonia or its salts into water before adding chlorine to it. The advantages of water preammonization are a decrease in chlorine consumption by $1.5-2$ times, reduction in distinct chlorine odor from water, and increase in the concentration of residual chlorine in purified water, which contributes to a longer dis- infection effect provided by combined chlorine (chloramines) [16, 17].

The practices in water preammonization in Moscow, St. Petersburg, Khabarovsk, Rostov-on-the-Don, and Nizhny Novgorod have shown a positive effect produced by this method for water conditioning and purification on quality of drinking water supplied to population, mainly due to reduction in the amount of chlorination by-products $[4,18-21]$.

This study was carried out on the territory of Arkhangelsk, the administrative center of the Arkhangelsk region, a city that is located in the Russian Arctic Zone ${ }^{2}$. The main source of centralized water supply in Arkhangelsk is the Northern Dvina with its channels with 10 waterworks being operated on them. The characteristic features of the Northern Dvina are low water temperature, low water salt and fluorine content, low total hardness, significant fluctuations in turbidity, intense color and high oxidizability $^{3}$.

Intense color of water - as much as $180^{\circ}$ in the area at the water intake - is attributable to natural humic substances as well as to waste discharges from the Arkhangelsk Pulp and Paper Mill, with a share being no less than $60 \%$ in total output of contaminated wastewater within the sanitary protection zone around the water source ${ }^{4}$. In addition, untreated or insufficiently treated municipal waste and storm water are discharged by sewage treatment plants of Arkhangelsk, housing without sewage, and enterprises operating in river and railway transport sectors.

The analysis of water quality in the Northern Dvina near Arkhangelsk revealed that a share of samples analyzed in 2017-2019 deviating from sanitary-hygienic standards as

\footnotetext{
${ }^{1}$ Guidelines for drinking-water quality: fourth edition incorporating the first addendum. Geneva: World Health Organization, $2017,470 \mathrm{p}$.

${ }^{2}$ Decree of the President of the Russian Federation issued on 2 May 2014 No. 296. On Land Territories of the Arctic Zone of the Russian Federation. ConsultantPlus. Available at: http://www.consultant.ru/document/cons_doc_LAW_162553/ (March 14, 2021).

${ }^{3}$ Shraga M.Kh., Bobun I.I., Mironovskaya A.V., Kudrya L.I., Gordyenko T.A., Unguryanu T.N. Hygiene of drinking water: textbook. 3rd edition. Arkhangelsk, Northern State Medical University Publ., 2015, 224 p.

${ }^{4}$ Order of the Ministry of Natural Resources and Environment of Russia of 18 April 2018 No. 154. On approval of the list of facilities that have a negative impact on the environment, related to category I, whose contribution to the total emissions, discharges of pollutants in the Russian Federation is no less than 60 percent. ConsultantPlus. Available at: http://www.consultant.ru/document/cons_doc_LAW_301627/(March 14, 2021).
} 
per microbiological and sanitary-chemical indicators, was 48.8 and $56.3 \%$, respectively, and it was by 2-3 times higher than the same rates in the Russian Federation. A percentage of drinking water samples analyzed in 20172019 on the territory of Arkhangelsk, deviating from sanitary-hygienic standards as per microbiological and sanitary-chemical indicators was 6.3 and $30.7 \%$, respectively, and it was by 2.5 times higher than the same rates in the Russian Federation on the whole ${ }^{5}$. The assessment of water quality monitoring in centralized water supply systems on the territories included in the Russian Arctic Zone showed that chloroform was one of the key contaminants in drinking water in Arkhangelsk region [22]. Thus, to improve quality of drinking water supplied to the population in Arkhangelsk, it is required to upgrade the water treatment system.

Preammonization of water was introduced at the central water treatment facilities (CWTFs) that supplied water to $77 \%$ of the population in Arkhangelsk. In 2017, Municipal Unitary Enterprise «Vodokanal» developed a pilot testing program for water ammonization technology that was approved by the Federal Service for Surveillance over Consumer Rights Protection and Human Well-being (Rospotrebnadzor) in Arkhangelsk Region. It was aimed at reducing contents of chlorinated organic derivatives remaining in drinking water due to its chlorination. In the period from August 2017 to May 2018, laboratory and pilot tests for implementing water ammonia technology were carried out using ammonium sulfate. In June 2018, preammonization of water at CWTFs was introduced on a permanent basis.

The purpose of the study is to assess the efficiency of water preammonization implementation at the central wastewater treatment plants in Arkhangelsk.

Materials and methods. The study analyzed quality of drinking water after water conditioning and purification at CWTFs prior to preammonization (from January 2016 to July
2017) and after it (from June 2018 to December 2019). 14,674 samples were analyzed prior to water preammonization was implemented, and 15,165 samples were analyzed after it was done. Exposed population involved in the study amounted to 273,624 people. The efficiency of preammonization implementation was assessed according to the data from in-process laboratory testing carried out by the organization operating CWTFs at re-lift pumping plants immediately after water conditioning and purification and at control points in the supply net, as well as according to the results obtained via supervisory activities performed by Rospotrebnadzor Department in Arkhangelsk region and laboratory investigations reports on drinking water quality completed by the Federal State-Funded Healthcare Institution "Centre for Hygiene and Epidemiology in Arkhangelsk Region" within socio-hygienic monitoring. The analysis included the data on consumption of chemicals prior to the implementation of preammonization and after it which were provided by the organizations (Municipal Unitary Enterprise "Vodokanal" and LLC RVK-Arkhangelsk) responsible for operating CWTFs.

The results of the study allowed the investigators to create a database on quality of drinking water supplied from CWTFs as per organoleptic, sanitary-chemical and microbiological indicators. Water quality was analyzed as per 19 indicators: organoleptic properties (odour at $20{ }^{\circ} \mathrm{C}$, color, and turbidity), complex indices (hydrogen ion concentration, permanganate oxidizability, and total dissolved solids), inorganic substances (aluminum, iron, chlorides, sulfates, ammonia, nitrites, nitrates) and chemical compounds formed during water treatment (chloroform, free residual chlorine, residual combined chlorine) and microbiological indices (total coliforms, thermo-tolerant coliforms and total microbial count).

Non-carcinogenic effects caused by exposure to chemicals contained in drinking water, prior to the implementation of preammoniza-

\footnotetext{
${ }^{5}$ On the Sanitary and Epidemiological Wellbeing of the Population in the Russian Federation in 2019: State report. Moscow, Federal Service for Surveillance on Consumer Rights Protection and Human Wellbeing (Rospotrebnadzor) Publ., 2020, 299 p.; On the Sanitary and Epidemiological Wellbeing of the Population of the Arkhangelsk region in 2019: State report. In: R.V. Buzinova ed. Arkhangelsk, 2020, 148 p.
} 
tion and after it, were assessed via calculating hazard quotients $(H Q)$ and hazard indices $(H I)$ for substances with a unidirectional action. Hazard quotients were calculated for aluminum, iron, ammonia, nitrites, nitrates and chloroform in their median concentrations. To calculate a dose of chemicals taken with drinking water, a water intake rate for the average adult (2L per day for a person weighing $70 \mathrm{~kg}$ ) was used. The total $H Q$ and $H I$ values lower than 1.0 were considered to be the minimum risk levels ${ }^{6}$.

To describe the content of the analyzed indicators, the median $(\mathrm{Me})$ and the 90 -th percentile $\left(\mathrm{P}_{90}\right)$ were used. Differences between the indicators of drinking water quality prior to the implementation of preammonization and after it were detected with Wilcoxon two-sample test. The critical level of statistical significance, $p$, was equal to 0.05 . Statistical data analysis was performed using STATA 14.2 software.

Results and their discussion. Currently, Arkhangelsk water supply services from CWTFs are being operated by LLC RVKArkhangelsk (previously, Municipal Unitary Enterprise "Vodokanal" till 20 December, 2018). CWTFs comprise two water treatment plants (No. 2 and 3) where water is prepared and disinfected, to be then supplied to a cleanwater reservoir. On average, CWTFs produce 130-140 thousand $\mathrm{m}^{3} /$ day.

CWTFs use two methods to purify water: coagulation in a free volume at plant No. 2, and coagulation in a filtering layer at plant No. 3. During water conditioning and purification at plant No. 2, water from the Northern Dvina comes to a vortex mixer, and then goes into water conduits, where ammonium sulfate is added to react with free chlorine to form bound chlorine. After that, to ensure primary disinfection, sodium hypochlorite and soda ash, coagulant and flocculant, are added into water. The ratio of ammonium nitrogen to active chlorine is 1:4. Further, water mixed with the chemicals arrives at high-speed filters through the reaction chambers, and then un- dergoes secondary disinfection and enters reservoirs with pure drinking water.

During water conditioning and purification at plant No. 3, water from the Northern Dvina is fed into a contact chamber, where ammonium sulfate solution, sodium hypochlorite (primary chlorination) and coagulant are added. When water leaves the contact chamber, it is mixed with the flocculant and enters contact coagulation pre-filters (contact flocculators). In addition, a micro-dose of flocculant is introduced into purified water. Then the second dose of sodium hypochlorite and soda ash solution are added into the water. After rapid filters, purified water undergoes final disinfection and is pumped into reservoirs with pure drinking water, where it is mixed with water coming from plant No. 2.

Assessment of water quality at the re-lift pumping plant of CWTFs. A comparative assessment of drinking water quality sampled at the re-lift pumping plant of CWTFs, taken as per average values of the indicators, showed an increase in color by 1.1 times $(p=0.027)$ and an increase in ammonia concentration (in terms of nitrogen) by 3.8 times $(p<0.001)$. At the same time, color and ammonia content at the median level did not exceed the threshold limit values (Table 1).

The quality of drinking water at the re-lift pumping plant of CWTFs at the median level for such indicators as odor, turbidity, $\mathrm{pH}$ value, permanganate oxidizability, iron and nitrites content did not change after preammonization was implemented $(p>0.05)$.

After water preammonization was implemented, the content of substances in drinking water decreased statistically significantly as to the following values: aluminum, by 2.7 times $(p<0.001)$; chlorides, by 1.7 times $(p<0.001)$; nitrates, by 1.2 times $(p<0.001)$. The concentration of chloroform at the re-lift pumping plant of CWTFs decreased by 3.5 times at the Me level, and by 5.5 times at the $\mathrm{P}_{90}$ level $(p<0.001)$ after water preammonization was implemented. It was not possible to assess effects produced by

\footnotetext{
${ }^{6}$ Guide on Health Risk Assessment under Exposure to Chemicals that Pollute the Environment. Moscow, Federal Center of Rosepidnadzor of the Ministry of Health of Russia Publ., 2004, 143 p.
} 
Table 1

Laboratory tests results showing drinking water quality at the re-lift pumping plant of CWTFs in Arkhangelsk

\begin{tabular}{|c|c|c|c|c|c|c|}
\hline \multirow[t]{2}{*}{ Indicator } & \multicolumn{2}{|c|}{$\begin{array}{c}\text { Prior } \\
\text { to preammonization }\end{array}$} & \multicolumn{2}{|c|}{$\begin{array}{c}\text { After } \\
\text { preammonization }\end{array}$} & \multirow[t]{2}{*}{$p$} & \multirow{2}{*}{$\begin{array}{c}\text { Normal } \\
\text { value }^{7}\end{array}$} \\
\hline & $M e$ & $P_{90}$ & $M e$ & $P_{90}$ & & \\
\hline \multicolumn{7}{|c|}{ Organoleptic indicators } \\
\hline Odor at $20^{\circ} \mathrm{C}$, points & 1 & 2 & 1 & 2 & 0.466 & 2 \\
\hline Color (colority), degrees & 12 & 18 & 13 & 21 & 0.027 & 20 \\
\hline Turbidity, mg/L (Kaolin) & 0.58 & 1.10 & 0.58 & 0.62 & 0.106 & 1.5 \\
\hline \multicolumn{7}{|c|}{ Complex indicators } \\
\hline Hydrogen ion concentration, $\mathrm{pH}$ units & 6.9 & 7.4 & 6.8 & 7.3 & 0.742 & $6-9$ \\
\hline Permanganate oxidizability, mg/L & 4.1 & 5.0 & 4.3 & 5.0 & 0.369 & 5 \\
\hline Total dissolved solids (solid residue), $\mathrm{mg} / \mathrm{L}$ & 268 & 362 & 209 & 322 & 0.008 & 1000 \\
\hline \multicolumn{7}{|c|}{ Inorganic substances } \\
\hline Aluminum $(\mathrm{Al}(3+)), \mathrm{mg} / \mathrm{L}$ & 0.32 & 0.46 & 0.12 & 0.24 & $<0.001$ & 0.5 \\
\hline Iron $(\mathrm{Fe}$, total $), \mathrm{mg} / \mathrm{L}$ & 0.1 & 0.14 & 0.1 & 0.15 & 0.107 & 0.3 \\
\hline Chlorides (in terms of CL), $\mathrm{mg} / \mathrm{L}$ & 16.05 & 20.3 & 9.7 & 13.8 & $<0.001$ & 350 \\
\hline Sulfates $\left(\mathrm{SO}_{4}\right), \mathrm{mg} / \mathrm{L}$ & 77.9 & 116.4 & 83.3 & 113.5 & 0.650 & 500 \\
\hline Ammonia (in terms of nitrogen) & 0.10 & 0.38 & 0.38 & 0.60 & $<0.001$ & 2.0 \\
\hline Nitrites (in terms of $\mathrm{NO}_{2}$ ), $\mathrm{mg} / \mathrm{L}$ & 0.02 & 0.02 & 0.02 & 0.03 & 0.014 & 3.0 \\
\hline Nitrates (in terms of $\mathrm{NO}_{3}$ ), $\mathrm{mg} / \mathrm{L}$ & 0.55 & 1.44 & 0.45 & 1.04 & 0.024 & 45 \\
\hline \multicolumn{7}{|c|}{ Chemical compounds occurring during water treatment } \\
\hline Chloroform, mg/L & 0.07 & 0.11 & 0.02 & 0.02 & $<0.001$ & 0.2 \\
\hline Free residual chlorine, $\mathrm{mg} / \mathrm{L}$ & 0.94 & 1.17 & 0.05 & 0.27 & 0.317 & NA \\
\hline Residual combined chlorine, $\mathrm{mg} / \mathrm{L}$ & 0.59 & 0.95 & 1.16 & 1.40 & 0.317 & $0.8-1.2$ \\
\hline \multicolumn{7}{|c|}{ Microbiological indices } \\
\hline Total coliforms, in $100 \mathrm{~mL}$ & 0 & 0 & 0 & 0 & $\mathrm{x}$ & None \\
\hline Thermo-tolerant coliforms, in $100 \mathrm{~mL}$ & 0 & 0 & 0 & 0 & $\mathrm{x}$ & None \\
\hline $\begin{array}{l}\text { Total microbial count (TMC), number of } \\
\text { colony forming bacteria in } 1 \mathrm{~mL}\end{array}$ & 0.03 & 0.41 & 0 & 0.26 & $<0.001$ & $\begin{array}{l}\text { Not more } \\
\text { than } 50\end{array}$ \\
\hline
\end{tabular}

Table 2

Laboratory tests results showing drinking water quality supplied to population through the Central Water Treatment Facilities in Arkhangelsk

\begin{tabular}{|c|c|c|c|c|c|c|}
\hline \multirow[t]{2}{*}{ Indicator } & \multicolumn{2}{|c|}{$\begin{array}{c}\text { Prior to } \\
\text { preammonization }\end{array}$} & \multicolumn{2}{|c|}{$\begin{array}{c}\text { After } \\
\text { preammonization }\end{array}$} & \multirow[t]{2}{*}{$p$} & \multirow{2}{*}{$\begin{array}{c}\text { Normal } \\
\text { value }^{6}\end{array}$} \\
\hline & $M e$ & $P_{90}$ & $M e$ & $P_{90}$ & & \\
\hline \multicolumn{7}{|c|}{ Organoleptic indicators } \\
\hline Odor at $20^{\circ} \mathrm{C}$, points & 1 & 1.3 & 1 & 1.3 & 0.114 & 2 \\
\hline Color (colority), degrees & 15 & 20 & 18 & 23 & $<0.001$ & 20 \\
\hline Turbidity, mg/L (Kaolin) & 0.86 & 1.47 & 0.66 & 1.02 & 0.002 & 1.5 \\
\hline \multicolumn{7}{|c|}{ Complex indicators } \\
\hline Hydrogen ion concentration, $\mathrm{pH}$ units & 6.9 & 7.4 & 6.9 & 7.3 & 0.684 & $6-9$ \\
\hline Permanganate oxidizability, mg/L & 4.1 & 5.2 & 4.4 & 4.8 & 0.547 & 5 \\
\hline Total dissolved solids (solid residue), $\mathrm{mg} / \mathrm{L}$ & 277 & 363 & 199 & 310 & 0.023 & 1000 \\
\hline \multicolumn{7}{|c|}{ Inorganic substances } \\
\hline Aluminum $(\mathrm{Al}(3+)), \mathrm{mg} / \mathrm{L}$ & 0.25 & 0.42 & 0.15 & 0.24 & $<0.001$ & 0.5 \\
\hline Iron $(\mathrm{Fe}$, total $), \mathrm{mg} / \mathrm{L}$ & 0.31 & 0.48 & 0.32 & 0.64 & 0.576 & 0.3 \\
\hline Chlorides (in terms of CL), $\mathrm{mg} / \mathrm{L}$ & 17.35 & 22.30 & 10.73 & 15.88 & $<0.001$ & 350 \\
\hline
\end{tabular}

\footnotetext{
${ }^{7}$ SanPiN (Sanitary Rules and Norms) 2.1.4.1074-01. Drinking Water. Hygienic Requirements for the Quality of Water from Centralized Drinking Water Supply Systems. Quality control. Moscow, Ministry of Public Health of Russia, 2002,103 p.
} 


\begin{tabular}{|c|c|c|c|c|c|c|}
\hline \multirow[t]{2}{*}{ Indicator } & \multicolumn{2}{|c|}{$\begin{array}{c}\text { Prior to } \\
\text { preammonization }\end{array}$} & \multicolumn{2}{|c|}{$\begin{array}{c}\text { After } \\
\text { preammonization }\end{array}$} & \multirow[t]{2}{*}{$p$} & \multirow{2}{*}{$\begin{array}{l}\text { Normal } \\
\text { value }^{6}\end{array}$} \\
\hline & $\mathrm{Me}$ & $P_{90}$ & $M e$ & $P_{90}$ & & \\
\hline Sulfates $\left(\mathrm{SO}_{4}\right), \mathrm{mg} / \mathrm{L}$ & 71.8 & 122.6 & 74.7 & 105.6 & 0.327 & 500 \\
\hline Ammonia (in terms of nitrogen) & 0.11 & 0.22 & 0.43 & 0.66 & $<0.001$ & 2.0 \\
\hline Nitrites (in terms of $\mathrm{NO}_{2}$ ), $\mathrm{mg} / \mathrm{L}$ & 0.02 & 0.02 & 0.03 & 0.12 & $<0.001$ & 3.0 \\
\hline Nitrates (in terms of $\mathrm{NO}_{3}$ ), $\mathrm{mg} / \mathrm{L}$ & 0.73 & 1.42 & 0.54 & 1.38 & 0.31 & 45 \\
\hline \multicolumn{7}{|c|}{ Chemical compounds formed during water treatment } \\
\hline Chloroform, mg/L & 0.066 & 0.085 & 0.009 & 0.043 & $<0.001$ & 0.2 \\
\hline Free residual chlorine, $\mathrm{mg} / \mathrm{L}$ & 0.10 & 0.25 & 0.01 & 0.14 & $<0.001$ & NA \\
\hline Residual combined chlorine, $\mathrm{mg} / \mathrm{L}$ & 0.11 & 0.15 & 0.50 & 0.64 & $<0.001$ & NA \\
\hline \multicolumn{7}{|c|}{ Microbiological indices } \\
\hline Total coliforms, in $100 \mathrm{~mL}$ & 0 & 0.04 & 0 & 0.04 & 0.888 & None \\
\hline Thermo $=$ tolerant coliforms, in $100 \mathrm{~mL}$ & 0 & 0.03 & 0 & 0.02 & 0.829 & None \\
\hline $\begin{array}{l}\text { Total microbial count (TMC), number of } \\
\text { colony forming bacteria in } 1 \mathrm{~mL}\end{array}$ & 0.05 & 0.68 & 0.05 & 0.36 & 0.580 & $\begin{array}{c}\text { Not more } \\
\text { than } 50 \\
\end{array}$ \\
\hline
\end{tabular}

water preammonization on the content of free residual chlorine and residual combined chlorine due to the low number of observations before it was implemented $(n=4)$.

At the median level, the total microbial count (TMC) was not found after water preammonization was implemented; the TMC at the $\mathrm{P}_{90}$ level decreased by 1.6 times $(p<0.001)$ at the re-lift pumping plant of CWTFs.

Assessment of water quality in the supply net. Comparative assessment of quality of drinking water sampled in the supply net prior to preammonization and after it, did not reveal any changes in odor and hydrogen ion concentration $(p>0.05)$.

It was found that after preammonization was implemented, colority increased by 1.2 times at the median level, the ammonia concentration increased by 3.9 times $(p<0.001)$, and nitrites concentration increased by 1.5 times $(p<0.001)$ (Table 2). At the same time, the values of these indicators did not exceed the threshold limit values, with the exception of colority at the $\mathrm{P}_{90}$ level.

In the supply net, after preammonization was implemented, water turbidity decreased by 1.3 times $(p=0.002)$, the solid residue decreased by 1.1 times $(p=0.023)$, and concentration of aluminum and chlorides decreased by 1.7 and 1.6 times, respectively $(p<0.001)$. The average content of chloroform decreased by 7.3 times, and free residual chlorine decreased by 10 times $(p<0.001)$. An average concentration of residual bound chlorine in- creased by 4.5 times $(p<0.001)$. An increase in contents of residual bound chlorine in the supply net and a decrease in free residual chlorine indicate that chlorine remains in the supply net for a longer period, and it determines longer bactericidal effects produced by chlorine in the water supply net.

In comparison with the re-lift pumping plant, quality of water in the supply net in terms of iron content deteriorated owing to significant wear and tear of the water supply network in Arkhangelsk (70.7\%) and the large number of accidents in it. However, the iron content in water in the supply net prior to preammonization was implemented and after it did not show statistically significant differences.

A decrease in concentrations of solid residue, chlorides, nitrates and sulfates in drinking water at the re-lift pumping plant of CWTFs and in the supply net in Arkhangelsk is associated with water natural composition. A decrease in concentration of aluminum at the relift pumping plant of CWTFs and in the supply net doesn't result from water preammonization implementation.

After preammonization was implemented, contents of thermo-tolerant coliforms (TTCs) and TMC in water in the supply net decreased by 1.5 and 1.9 times, respectively, while the total coliforms number (TCs) remained unchanged.

The characteristics risks that developing general toxic effects would develop showed that values of the hazard quotients for all analyzed substances and the hazard indices for 
critical organs and systems, both prior to the implementation of preammonization and after it, did not exceed 1.0. Nevertheless, after the preammonization was implemented, the hazard indices for the blood and skin systems decreased by 3.2 times, and they decreased by 5-7 times for the circulatory system, central nervous system and digestive organs (figure).

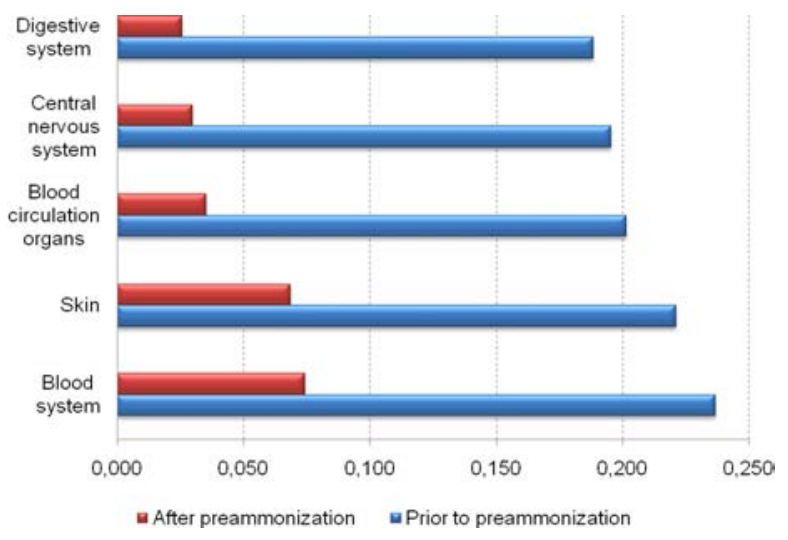

Figure. Hazard indices for critical organs and systems when exposed to chemicals contained in drinking water, prior to preammonization and after it was implemented

A decrease in a risk of developing general toxic effects on critical organs and systems was primarily attributable to a fall in contents of chloroform in drinking water after preammonization was implemented. A contribution made by chloroform in the hazard indices after preammonization was implemented went down by $10-47 \%$ as compared to water treatment based on traditional chlorination.

The major outcome gained via implementing water preammonization in Arkhangelsk was a decrease in chloroform contents in drinking water at the re-lift pumping plant from 0.07 to $0.02 \mathrm{mg} / \mathrm{L}$ and in the supply net from 0.066 to $0.009 \mathrm{mg} / \mathrm{L}$. The results of this study are consistent with the data obtained in St. Petersburg, where tests on implementing water ammonization with ammonium sulfate were carried out. As a result of preammonization at the water treatment facilities in St. Petersburg, chloroform contents in drinking water decreased from $90-120$ to $1-5 \mu \mathrm{g} / \mathrm{dm}^{3}$ [18].

In Khabarovsk, implementation of water preammonization with the use of ammonium sulfate allowed preventing drinking water quality form further deterioration as per microbi- ological indicators in the supply net and reducing contents of chlorinated organic compounds in drinking water lower than hygienic standards [19]. Water preammonization with ammonium sulfate became an effective way to reduce concentrations of chlorinated volatile organic compounds up to seven times in water supplied to population of Rostov-on-the-Don, Taganrog and Azov [20].

The implementation of water preammonization and the use of sodium hypochlorite at the Sludinskaya waterworks in Nizhny Novgorod made it possible to reduce concentrations of chloroform to no more than $0.01 \mathrm{mg} / \mathrm{L}$, as well as to reduce concentrations of disinfection by-products (DBPs) in drinking water by $60-80 \%$ [21]. Employees of OJSC "Mosvodokanal" carried out a study on implementation of water preammonization as a part of water treatment in Moscow; as a result chloroform concentrations decreased from 50-87 to $6-15 \mu \mathrm{g} / \mathrm{L}[4]$.

To reduce contents of chlorinated organic compounds in drinking water, preliminary ammonization and chlorination are the most efficient technology, but it results in occurrence of chloramines which diminish the effect of discoloration. This explains more intense color of water at the re-lift pumping plant of the wastewater treatment facilities $\left(1^{\circ}\right)$ and in the supply net $\left(3^{\circ}\right)$. OJSC "Mosvodokanal" carried out a number of laboratory tests to determine dependence between colority value on a dose and the order in which chlorine and ammonia were introduced into water. As a result, color reducing was not achieved: when ammonia was added 5 minutes after chlorine, color decreased only by $2^{\circ}[4]$.

According to data provided by LLC RVKArkhangelsk that operates CWTFs in Arkhangelsk, the total consumption of a chemical reagent (sodium hypochlorite) amounted to 318.2 tons in 2019. Prior to the implementation of water ammonization, the total consumption of the reagent was 666 tons per year. Therefore, after water preammonization was implemented, the consumption of this chemical reagent decreased by 2.1 times and it means reagent saving and economic efficiency of implemented 
water preammonization. At the Sludinskaya waterworks in Nizhny Novgorod, the implementation of preammonization helped reduce the chlorine consumption by $40-50 \%$ [21].

Conclusions. The use of ammonium sulphate for preliminary ammonization as part of water conditioning and drinking water purification at CWTFs in Arkhangelsk helped significantly improve quality of drinking water supplied to population. A positive effect achieved due to preammonization was a reduction in the amount of chlorination byproducts and improved microbiological quality of drinking water. A reduction in chloro- form contents decreases the risk of developing general toxic effects on critical organs and systems. Water preammonization as a new technology used at the stage of water treatment made it possible to improve quality of waterworks operation, reduce operating costs, decrease the amount of disinfection byproducts (DBPs) and improve drinking water quality.

Financing. The research was not granted any sponsor support.

Conflict of interests. The authors declare there is no conflict of interests.

\section{References}

1. Kosolapov V.P., Chaikina N.N., Sych G.V., Boldyreva E.A., Lastochkina K.S. Analysis of the state of drinking water in the Voronezh region for 2014-2019 years. Sistemnyi analiz i upravlenie v biomeditsinskikh sistemakh, 2020, vol. 19, no. 3, pp. 230-239 (in Russian).

2. Stepanov N.A., Zavodova E.I. Characteristics of drinking water quality influence on human health. Meditsina truda i ekologiya cheloveka, 2015, no. 3, pp. 200-205 (in Russian).

3. Mikhailichenko K.Yu., Korshunova A.Yu., Kurbatova A.I. Integrated assessment of drinking water quality of water supply systems. Vestnik RUDN. Seriya: Ekologiya i bezopasnost' zhiznedeyatel'nosti, 2014, no. 4, pp. 99-106 (in Russian).

4. Arutyunova I.Yu., Kalashnikova O.B. The use of preammonization and primary chlorination in the process of the Moskva river water purification. Vodosnabzhenie i sanitarnaya tekhnika, 2012, no. 10, pp. 18-22 (in Russian).

5. Miftakhova K.R., P'yankova O.G., Rudakova L.V., Glushankova I.S. Chlorination is the main method of disinfection of drinking water. Ekologiya i nauchno-tekhnicheskii progress. Urbanistika, 2015, vol. 1, pp. 233-242 (in Russian).

6. Alekseeva L.P. Snizhenie kontsentratsii khloroorganicheskikh soedinenii, obrazuyushchikhsya v protsesse podgotovki pit'evoi vody [A decrease in concentration of chlorinated organic compounds that occur during drinking water treatment]. Vodosnabzhenie i sanitarnaya tekhnika, 2009, no. 9, pp. 27-34 (in Russian).

7. Golovesov V.A., Pervov A.G. Issledovanie metodov snizheniya kontsentratsii khlororganicheskikh soedinenii pri podgotovke pit'evoi vody [A decrease in concentration of chlorinated organic compounds that occur during drinking water treatment]. Stroitel'stvo - formirovanie sredy zhiznedeyatel'nosti: XXI Mezhdunarodnaya nauchnaya konferentsiya: sbornik materialov seminara «Molodezhnye innovatsii». Moscow, Izdatel'stvo MISI-MGSU Publ., 2018, pp. 26-29 (in Russian).

8. Liu W., Zhao Y., Chow C.W., Wang D. Formation of disinfection byproducts in typical Chinese drinking water. Journal of Environmental Science (China), 2011, vol. 23, no. 6, pp. 897-903. DOI: 10.1016/s1001-0742(10)60493-7

9. Richardson S.D., Plewa M.J., Wagner E.D., Schoeny R., Demarini D.M. Occurrence, genotoxicity, and carcinogenicity of regulated and emerging disinfection by-products in drinking water: a review and roadmap for research. Mutation Research/Reviews in Genetic Toxicology, 2007, vol. 636, no. 1-3, pp. 178-242. DOI: 10.1016/j.mrrev.2007.09.001

10. Sadeghi H., Nasseri S., Yunesian M., Mahvi A.H., Nabizadeh R., Alimohammadi M. Trihalomethanes in urban drinking water: measuring exposures and assessing carcinogenic risk. Journal of Environmental Health Science and Engineering, 2019, vol. 12, no. 17 (2), pp. 619-632. DOI: 10.1007/s40201-019-00374-x

11. DeMarini D.M. A review on the 40th anniversary of the first regulation of drinking water disinfection by-products. Environmental and Molecular Mutagenesis, 2020, vol. 61, no. 6, pp. 588-601. DOI: $10.1002 / \mathrm{em} .22378$ 
12. Andersson A., Ashiq M.J., Shoeb M., Karlsson S., Bastviken D., Kylin H. Evaluating gas chromatography with a halogen-specific detector for the determination of disinfection by-products in drinking water. Environmental Science and Pollution Research International, 2019, vol. 26, no. 8, pp. 7305-7314. DOI: $10.1007 / \mathrm{s} 11356-018-1419-2$

13. Chen Y.J., Liu C., Huang L.L., Ai S.H., Sun L., Huang Z., Li J., Lei H.S. [et al.]. First-trimester blood concentrations of drinking water trihalomethanes and neonatal neurobehavioral development in a Chinese birth cohort. Journal of hazardous materials, 2019, vol. 15, no. 362, pp. 451-457. DOI: 10.1016/j.jhazmat.2018.09.040

14. Nadali A., Rahmani A., Asgari G., Leili M., Norouzi H.A., Naghibi A. The assessment of trihalomethanes concentrations in drinking water of Hamadan and Tuyserkan Cities, Western Iran and its health risk on the exposed population. Journal of Research in Health Sciences, 2019, vol. 6, no. 19 (1), pp. e00441.

15. Glazkov D.V. O primenenii metoda predvaritel'noi ammonizatsii vody r. Ob' [On using preliminary ammonization to treat water taken from the Ob' river] Voprosy stroitel'stva i inzhenernogo oborudovaniya ob"ektov zheleznodorozhnogo transporta: materialy nauchno-prakticheskoi konferentsii. Novosibirsk, Izd-vo SGUPSa Publ., 2017, 288 p. (in Russian).

16. Kinebas A.K., Nefedova E.D., Bekrenev A.V., Yakovlev V.Yu. Vnedrenie dvukhstupenchatoi skhemy obezzarazhivaniya vody na vodoprovodnykh stantsiyakh Sankt-Peterburga [Implementing a twostage water treatment procedure at water supply stations in Saint Petersburg]. Vodosnabzhenie i sanitarnaya tekhnika, 2010, no. 2, pp. 36-42 (in Russian).

17. Mileshkin S.I. Preammonizatsiya na stantsiyakh vodopodgotovki v gorodakh s bol'shoi protyazhennost'yu vodoprovodnykh setei [Preammonization at water supply stations in cities with long water supply systems]. Aktual'nye problemy stroitel'stva, ZhKKh i tekhnosfernoi bezopasnosti. In: N.Yu. Ermilova ed., 2017, pp. 58-60 (in Russian).

18. Kinebas A.K., Nefedova E.D., Bekrenev A.V., Yakovlev V.Yu. Ispol'zovanie sul'fata ammoniya v protsesse obezzarazhivaniya pit'evoi vody [Ammonia sulfate being used to treat drinking water]. Vodosnabzhenie $i$ sanitarnaya tekhnika, 2009, no. 6, pp. 49 (in Russian).

19. Arkhipova E.E., Aleshko D.S., Dunaevskaya E.V. The use of new water treatment technologies within the framework of the project «Expansion and reconstruction of a water pipe in Khabarovsk (second phase)». Vodoochistka. Vodopodgotovka. Vodosnabzhenie, 2018, no. 3, pp. 14-21 (in Russian).

20. Pedashenko D.D., Bozhko L.N., Skryabin A.Yu., Popov'yan G.V., Tkacheva T.I., Pelipenko L.V. Vliyanie obrabotki donskoi vody khlorreagentami na obrazovanie letuchikh khlororganicheskikh soedinenii [Impacts exerted by treating water taken from Don with chlorinated reagents on occurrence of volatile chlorinated organic compounds]. Vodosnabzhenie i sanitarnaya tekhnika, 2009, no. 9, pp. 58-62 (in Russian).

21. Pavlov A.A., Dziminskas Ch.A., Kostyuchenko S.V., Zaitseva S.G. Sovremennye tekhnologii podgotovki pit'evoi vody na Sludinskoi vodoprovodnoi stantsii Nizhnego Novgoroda [Up-to-date technologies applied for drinking water treatment at Sludinskaya water supply station in Nizhniy Novgorod]. Vodosnabzhenie i sanitarnaya tekhnika, 2010, no. 1, pp. 10-16 (in Russian).

22. Gorbanev S.A., Fedorov V.N., Tikhonova N.A. State and improvement of sanitary and epidemiological welfare management in the Russian Arctic. Ekologiya cheloveka, 2019, no. 10, pp. 4-14 (in Russian).

Sosnina S.A., Mironovskaya A.V., Unguryanu T.N., Buzinov R.V. Water preammonization at central water treatment facilities in a large city as a way to minimize health risks. Health Risk Analysis, 2021, no. 2, pp. 53-61. DOI: 10.21668/health.risk/2021.2.05.eng

Received: 17.03 .2021

Accepted: 04.06 .2021

Published: 30.09 .2021 